\title{
Fluorescent Dye Determination of Groundwater Movement and Contamination in Permeable Rock Strata
}

\author{
by
}

Charles P. GIAMMONA*

\section{INTRODUCTORY REMARKS}

Sanitary land-fill methods in the treatment of solid and liquid wastes are widely distributed, creating a potential health hazard for nearby groundwater used as a pure aquifer. Contaminants infiltrate the soil and disperse within its matrix. This solution eventually enters underground storage basins which, in turn, may be a source of potable water.

The magnitude of potential danger to groundwater emanating from the pollution source, or sources, and the degree of concern that should be given to it, is largely unknown. It is important to know the concentration of the water-miscile pollutants which travel through the soil. But this concentration varies greatly during the flow from the surface to the groundwater basin, creating problems during quantitative studies. A more feasible consideration regards water in the immediate vicinity of, and in direct contact with, the suspected sources of impurity. By following some of the innumerable flow paths, groundwater tracing techniques can be utilized to indicate variation in water quality relative to a contaminated area, and the extent of impervious bedrock that contains them.

This is a report made to furnish more specific conclusions than now available concerning groundwater quality as affected by subsurface drainage in southeastern Minnesota. Studies in several states have demonstrated that underground water reaching wells in unsewered areas contained chemicals and bacteria of sewage origin. In the metropolitan area of Minneapolis-St. Paul, Minnesota, the water from 55,000 wells in thirty-three communities was analyzed. The results indicated fifty percent of the wells tested were contaminated by sewage as evidenced by the presence of detergents or elevated nitrates (Peter, personal communication).

The only source of potable water for individuals and communities in Fillmore County, Minnesota, is underground aquifers. Protection of this source has been a growing concern for both the Health Department and general populus. The direct contamination of wells from inadequate septic tanks or cesspools has been decried for years. In an effort to protect wells against this contamination, legislation has provided minimum standards in the construction of disposal systems intended to implement sanitary treatment facilities.

* Department of Oceanography, Texas A\&M University, College Station, Texas 77843, USA. 
An overlooked concept in pollution has come to this author's attention, namely, underground contamination resulting from overland run-off. In Filmore County, and southeastern Minnesota in general, geological formations facilitate the spread of this pollution.

\section{METHODS}

The broad application of fluorescent dye as tracers has clearly established its superiority over other methods (Turner, 1968). Our interest in predicting pollution problems indicates the potential diagnostic capabilities of fluoresence in determining effluent dispersion within a recipient system.

As with many other analytical procedures, fluorescent assay does not require an extensive theoretical background of the phenomenon. However, some information concerning the physical principle of fluorescence is helpful in extending its applications.

Rhodamine WT from DuPont Chemical Company was employed as the fluorescent dye in our tracing. This new dye is in routine use for measuring dispersion characteristics. Although no report could be found on a toxicity study, it has been demonstrated that Rhodamine WT could be used intravenously in rats with no deleterious effects (Donaldson, 1968). It is available in both a water-soluble solid and liquid form, at $\$ 15.00$ per pound, and is comparatively inexpensive. These tracing studies utilized liquid Rhodamine WT. Its fluorescence intensity is

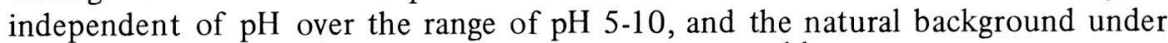
typical field conditions is less than 5 parts per $10^{11}$. Its major advantage is relatively low adsorption on soil and suspended sediment.

The Turner Model 111 Fluorometer was our detection instrument. A concentration of Rhodamine was measured by directing a low-pressure, 4-watt mercury light source exciting the known wavelength of $254 \mathrm{mu}$. on the sample. Colored glass filters, \#110-832 and \#110-833 were installed between the light and sample.

The fluorometer was placed at the suspected outlets of subterranean streams. A $500 \mathrm{ml}$ alliquot of concentrated liquid dye was added to several sinkholes in the area, ascertaining subsurface flow and simulating the dispersion of a possible pollutant. The amount of tracer usually injected depended upon the turbulence of the stream, with allowances for loss by adsorption. Because these were preliminary studies, the relatively high dye concentration was used to insure detection and measurement.

One advantage in the instantaneous injection method is that the dye is merely released, whereas a constant rate of injection requires a constant-head injection device. The main disadvantage of introducing dye in a single quantity is that it may be missed at the sampling point by momentary inattention or equipment failure.

\section{GEOLOGICAL CONSIDERATIONS}

The deep valleys of the Root River and its dendritic tributaries expose many of the 
sedimentary rock deposits of southeastern Minnesota, and specifically Fillmore County. Figure 1 presents a cross section of the geological rock layers in this area. It reveals the nearly horizontal layers of limestones, sandstones, dolomites and shales. Some formations are limited to certain areas in the county and are discontinuous. Other, particulary the older limestones and sandstones, are continuously stratified and underlie the entire county.

Examples of extreme mineral dissolution and erosion activity are the commercial Mystery Caves in Fillmore County. It is readily seen in traversing the caverns that no effective water filtration occurs in the soluble limestone formation. This cave system also illustrates the distance contaminated water can travel through limestone. Although few caves have been commercially developed in Fillmore County, the presence of sinkholes in the southeastern townships are evidence that extensive caverns exist near the grondund surface. Crevices and solution channels of all sizes have beer encountered in wells penetrating the limestone and dolomite formations underlying the entire county.

Three formations are important in understanding water supplies of this area: 1) Platteville limestone formation. It is of limestone composition with numerous vertical and horizontal irevices. Unlike other parts of the county, this formation is not a local water source in that it is a surface stone. 2) St. Peter sandstone formation. This formation is found underlying the Platteville limestone. Because it is nearly one hundred feet thick and because it is a sandstone layer, contaminated materials cannot move through it. Unfortunately, the possibility is that it has been penetrated by uncased wells in areas where its natural filtration ability would

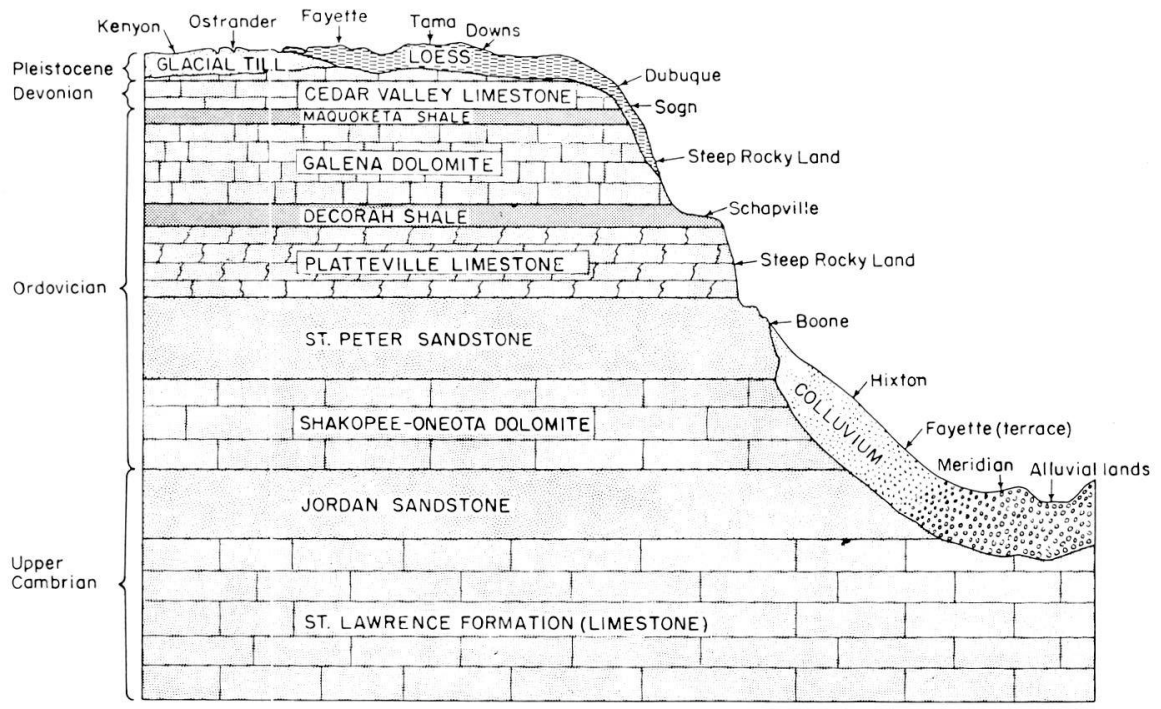

Fig. 1. Schematic cross-section of a valley, showing geologic formations and miscellaneous land types. 
normally have protected underlying formations. 3) Shakopee dolomite formation. Under the St. Peter sandstone lies the Shakopee dolomite formation which underlies nearly all of the county. It is creviced and provides avenues through which contaminated materials can move freely.

\section{DATA ANALYSIS AND INTERPRETATION}

Figure 2 illustrates paths of dye movement and suspected subterranean draining avenues. The distance the dye has traveled from sinkholes to springs ranges over several miles. These ranges probably extend beyond the immediate study area. Note the presence of strip mines and tailing ponds. Agricultural run-off is apparent and septic system leaching pits are the common method of waste disposal. Although the populated areas are sparce, the potential danger from a contaminant in the system is obvious.

The problem relating to Fillmore County's geological construction concerns the interconnection of pervious and impervious bedrock. Contaminated materials enter the underlying limestone or dolomite which would have been protected by an intervening sandstone layer under natural conditions. This situation arises most frequently where the Root Valley has faulted, connecting the Platteville limestone and Shakopee dolomite. For the above reason, this formation could be the geological villain of the area. The Platteville limestone is covered by a thin layer of earth. Consequently, it has become the partial source of many water supplies, as well as the repository of much sewage in the area.

The problem associated with groundwater supplies in this area is the same throughout the county. Distances that contaminated materials can move underground are so extensive that the isolation of a well, as in the case of a farm, does not offer dependable water protection. Sinkholes and natural exposures of creviced limestone constitute avenues through which surface run-off can enter these formations. Other opportunities exist for the introduction of pollutants into an aquifer. In any specific geological formation, sources of contamination include: 1) wells inadequately distant from disposal units whereby sewage can enter the well, 2) discarding refuse into crevices where the impervious rock is insufficient to allow adequate purification, 3) the practice of discharging sewage into abandoned wells or sinkholes, 4) agricultural run-off from farm lands into subterranean channels which is later recycled as potable water by wells drilled in the same formation.

The entrance of any considerable amount of sewage into one area could contaminate all nearby wells developed within the same formation. This problem is further complicated by the need to drill to the Shakopee dolomite strata for water. In such instances, a well which is inadequately cased while penetrating contaminated formations, becomes hazardous to adjacent water systems from the Shakopee strata.

It can be inferred that one of the biggest culprits is detergent leaching into the subsoil. Once into the underground water system, the contamination of a few wells may contaminate a whole aquifer. In the case of stream pollution, there will be a 


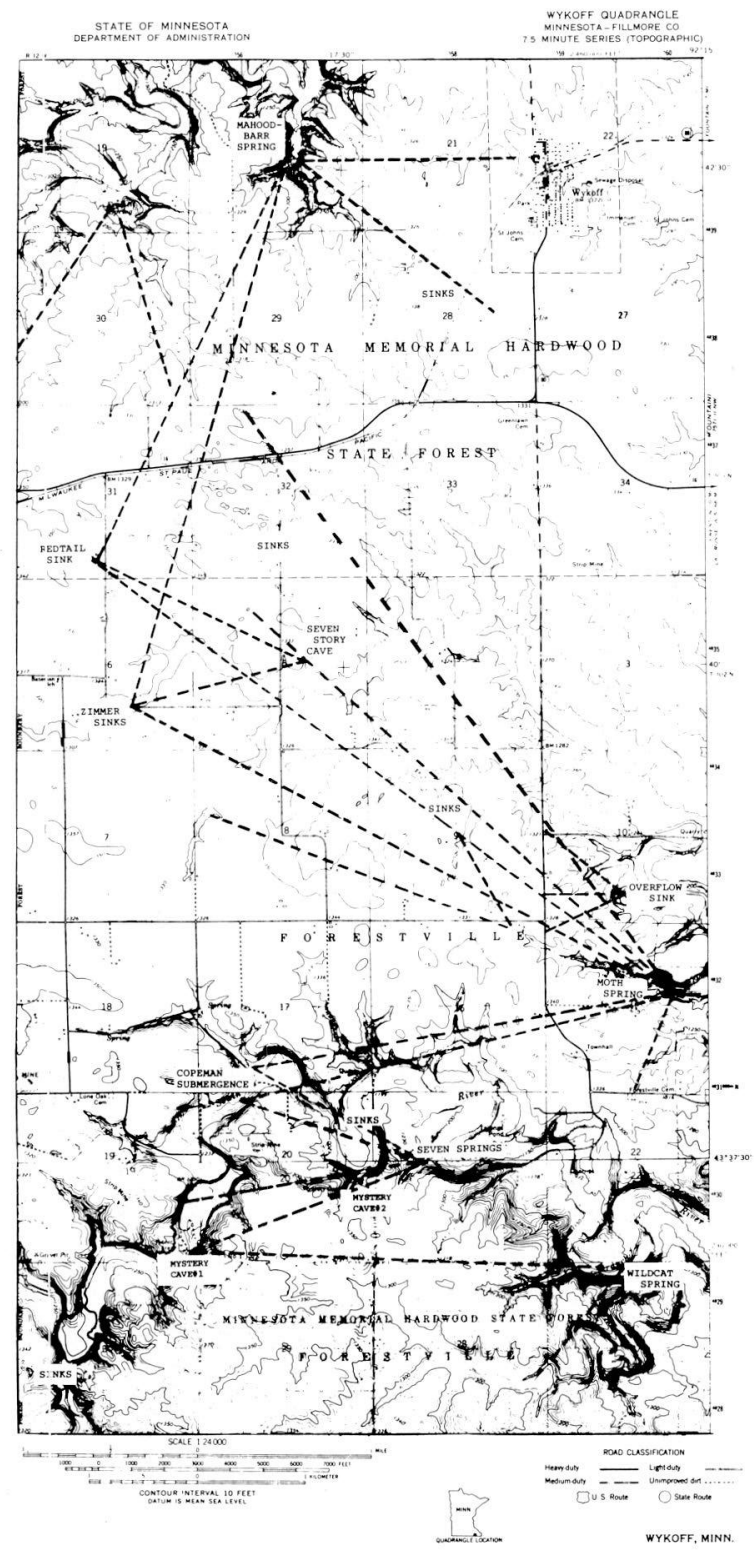

Fig. 2. Topographical map representing general locations of suspected subterranean drainage avenues. Also pictured are the numerous potholes and sinks in the region, indicating the vast areas of unexplored channels. 
dilution factor during maximum flow conditions, and wastes can disperse rather rapidly. In the case of groundwater, because of its naturally slow translocation, the contaminants linger indefinitely.

Soil chemistry has not been considered during this study. The relationship between soil type and vegetation in Fillmore County is difficult to ascertain because few areas are in a native state. Evidence of trees encroaching upon the prairie is common, particularly along streams and drainageways. Prairie grasses, in general, help maintain a high base status, promote aggregation, and intensify the dark color of soils by increasing the organic content. On the other hand, the deep-rooted trees promote acidity and increase soil leaching. That there is actual flushing of debris to interconnected openings is well documented by observation of "muddy waters" pumped into adjacent area homes. In other ares, low $\mathrm{pH}$ water samples have been recorded (U.S.D.A., 1958). It is apparent then, that soil encroachment is very complex and that its effects have been extremely variable.

Since Dole (1906) extolled the use of fluorescence in mapping subterranean water, there has been little literature on fluorescent dyes for tracing subsurface flow. Even fluorescein, which has low soil adsorption, is retarded or eventually lost to calcareous soils, peaty formations, and free acids. Since the ideal groundwater tracer does not seem to exist (even radioactive traces are lost or retarded, depending on the strata), and since fluorescent dyes are safe and inexpensive, they are primary candidates for qualitative studies of subsurface interconnections. The downstream movement of dye is conclusive, although its failure to appear is not. The retention capacity of soil is limited, however, and for short distances it is economically feasible to use a quantity of tracer sufficient to support a negative result.

\section{CONCLUDING REMARKS}

Avenues through which contaminated materials can travel, arrangement of the rock strata, and the opportunities for contaminated materials to enter them, must be understood in order to afford aquifer protection. The Shakopee dolomite, which underlies all of Fillmore County, is subject to contamination with sewage and surface water. This results from the practice of discharging sewage from individually owned disposal systems into the dolomite, or into the soil directly above it. Because extensive and rapid movement of contaminated material in this stratum is possible, all residential groundwater supplies in Fillmore County are probably exposed to this pollution.

It is reasonable to expect that concentrations of contaminated materials will increase in the water with time. Because non-degradable chemicals are by no means the only component which may be present in sewage, and because there are various ways in which toxic substances may become constituents of sewage, there is a possibility that water from any individual water supply, contaminated as indicated, may contain toxic materials.

With the knowledge of the faulted nature of the Shakopee dolomite and the opportunity for rapid and widespread movement of contaminated water within it, 
water supplies not now polluted may become so at any time. Moreover, uncased wells that extencl through dolomite formations can conduct contaminated water rapidly and in quantity from one stratum to another.

\section{ACKNOWLEDGEMENTS}

I wish to express my gratitude to Dr. C. D. McNabb, Edward Miller, and Dr. Seymour Sohmer. To the following I am also indebted: Clarence Proshka in the use of Mystery Caves, Neil Saylor and the Minnesota Speleological Society, and the Minnesota Department of Health, District No. 3.

\section{SUMMARY}

A preliminary inquiry to the extent and boundaries of subterranean waterways within the Mystery Cave System was explored. Rhodamine WT dye in $500 \mathrm{ml}$ quantities was used in fluormetry determinations of surface flow to ground water basins. A Turner Model 111 fluorometer was utilized for detection purposes powered by a portable 12 volt, $220 \mathrm{amp}$ hour battery-inverter system.

It was shown that water entered underground passageways through sinkholes or highly creviced limestone/dolomite rock strata and reappeared several kilometers downstream. The outflow appears in the form of "springs".

The possibility exists that contaminated surface water may seep through the soil for long distances. It is obvious there is acute danger of underground contamination of municipal and private water supplies situated in this area.

\section{RESUME}

Une recherche préliminaire a été faite sur l'étendue et les limites des cours d'eau souterrains dans le "Mystery Cave System". L'écoulement des eaux, de la surface vers les bassins souterrains, a été déterminé par fluorométrie en utilisant comme colorant la rhodamine WT à des doses de $500 \mathrm{ml}$. La détection a été faite au moyen d'un fluoromètre 'Turner Model 111 alimenté par un accumulateur portatif de $12 \mathrm{~V}$, $220 \mathrm{~A} / \mathrm{h}$.

Il a été montré que l'eau gagnait le réseau souterrain par des dolines ou des fissures de la couche de calcaire dolomitique, et réapparaissait plusieurs kilomètres en aval. L'effluent se présente sous la forme de "sources",

Il est possible c $q$ ue l'eau contaminée en surface s'infiltre dans le sol sur de longues distances. Il est évident qu'il y a là un grand danger de pollution des eaux souterraines de cette région, qui alimentent la municipalité et les particuliers. 


\section{REFERENCES}

DOLE, R.B. 1906: Use of Fluorescein in the Study of Underground Waters. U. S. Geological Survey. Water Supply Paper 160, pp. 73-85.

DONALDSON, Donald. 1968: On the toxic effect of several fluorescent dyes. U. S. Geological Survey Study, unpublished manuscript.

TURNER, G.K. (ed.) 1968: Fluorometry in Studies of Pollution and Movement of Fluids. Turner Associates, Palo Alto, California, 23 pp.

United States Department of Agriculture, Soil Conservation Service. 1958: Soil Survey: Fillmore County, Minnesota. 1954, pp. 1-12. 